\title{
Tinjauan Perilaku Konsumtif Masyarakat Pesisir Dalam Islam (Studi Kasus pada Masyarakat Pesisir Desa Bandaran, Kecamatan Tlanakan, Kabupaten Pamekasan)
}

\author{
Aldila Septiana \\ STKIP PGRI Bangkalan \\ aldilaseptiana@yahoo.co.id
}

DOI: https://doi.org/10.21107/dinar.v5i1.4639

\begin{abstract}
ABSTRAK
Fokus penelitian ini mengangkat permasalahan bagaimana perilaku konsumtif dalam tinjauan Islam dan cara memaknai kata maslahah dalam perilaku konsumsi masyarakat pesisir di Desa Bandaran, Kecamatan Tlanakan, Kabupaten Pamekasan?

Metodologi penelitian ini menggunakan pendekatan fenomenologi dimana peneliti mengidentifikasi hakikat pengalaman manusia tentang suatu fenomena. Peneliti memilih jenis penelitian fenomenologi karena ingin memahami dan mengungkapkan fenomena perilaku konsumsi masyarakat pesisir di Desa Bandaran, Kecamatan Tlanakan, Kabupaten Pamekasan yang terjadi di lapangan secara alami, utuh, dan akurat sehingga penelitian ini hanya bisa dilakukan dengan menggunakan penelitian kualitatif dengan pendekatan fenomenologi.

Hasil penelitian menunjukkan babwa perilaku konsumsi masyarakat pesisir dengan mayoritas bekerja sebagai nelayan, mereka mencari nafkah pagi, siang, sore dan babkan malam. Sekalipun mereka memiliki semangat dalam urusan ekonomi dan konsumsinya. Perilaku konsumtif masyarakat pesisir dalam tinjauan Islam, dalam satu sisi, pelestarian seperti ini sangat perlu dilestarikan karena ikut mennyumbangkan warisan budaya tetap terjaga, serta turut menjaga ukhuwah islamiah karena mampu menghadirkan banyak orang dalam tablilan ini. Serta dalam memaknai kata "Maslahab" pada perilaku konsumsinya sangat peduli antar sesama dan menjunjung kemaslahatan dalam melakukan kegiatan konsumsinya.
\end{abstract}

Kata Kunci: Perilaku Konsumsi, Konsumtif, Islam, Maslahah 


\section{PENDAHULUAN}

Pada hakikatnya manusia adalah homo economicus, kata ini berasal dari bahasa latin yang artinya manusia ekonomi. Homo economicus merupakan sosok manusia yang rasional dan berkebebasan dalam menentukan pilihan-pilihan yang ada untuk mencapai tujuan tertentu. Sehingga dalam setiap perilakunya manusia harus lebih bersifat rasional dalam memilih sumber daya yang ada (Case, 2007: 29). Namun, pada kenyataannya perilaku manusia khususnya perilaku konsumsi lebih mengarah pada perilaku konsumtif (Dinar \& Hasan, 2018). Jika diperhatikan lebih lanjut, perilaku konsumtif ini cenderung terjadi di masyarakat yang ada di sekitar kita. Dapat dicontohkan bahwa masyarakat pesisir yang akan dijadikan fokus dalam penelitian ini, kecenderungan sangat konsumtif. Hal ini ditandai dengan adanya banyak penjual makanan di sepanjang jalan Desa Bandaran, Kecamatan Tlanakan, Kabupaten Pamekasan.

Masyarakat pesisir yang menjadi fokus penelitian merupakan masyarakat yang bertempat tinggal di sekitar daerah pantai. Dengan mata pencaharian utama sebagai nelayan, walaupun tidak menutup kemungkinan terdapat sektor perdagangan yang menjadi mata pencaharian. Jika diperhatikan lebih lanjut sepanjang jalan Desa Bandaran, Kecamatan Tlanakan, Kabupaten Pamekasan terdapat fenomena yang sangat unik untuk dapat ditelusuri yaitu berkenaan dengan perilaku konsumsi masyarakat pesisir.

Untuk lebih jelasnya yaitu terletak di Desa Bandaran, Kecamatan Tlanakan, Kabupaten Pamekasan yang terdiri dari enam dusun yaitu Pandien, Manceng, Majeng, Tanjung, Dengkah, serta Deman. Seperti yang telah disebutkan di atas bahwa mayoritas masyarakat di sana memiliki mata pencaharian sebagai nelayan. Lokasi ini cukup menarik untuk diteliti karena kesuburan ekonomi dan perkembangannya yang cukup pesat ada suatu hal yang unik rata-rata masyarakat yang ada di sebelah barat masjid pasar masyarakat di sana kebanyakan memiliki mata pencaharian sebagai nelayan tulen sedangkan sebaliknya dari masjid ke timur mereka sebagian memiliki mata pencaharian sebagai nelayan, guru, pegawai di kantor pemerintahan, pegawai swasta, serta yang menekuni bidang perdagangan. Hal ini ditunjukkan dengan banyaknya pertokoan yang berjejer menjual kebutuhan masyarakat, dan lain sebagainya.

Desa ini juga terletak di daerah pesisir pantai dan juga terletak di pinggir jalan raya yang menghubungkan Kabupaten Sampang dan Pamekasan. Hal ini menunjukkan bahwa Desa Bandaran ini merupakan tempat yang strategis bagi mereka dalam mengembangkan roda ekonomi. Dimana salah satu yang dapat dimanfaatkan adalah kemudahan akses dalam penjualan hasil-hasil laut yang diperoleh nelayan. Selain itu, dari sektor perdagangan juga dapat dimanfaatkan oleh masyarakat dengan menjual beraneka macam makanan khas dari Desa Bandaran.

Kegiatan konsumsi merupakan salah satu kegiatan yang pokok dalam sendi kehidupan makhluk hidup. Dalam hal ini, terkadang konsumsi yang dimaksud adalah tidak hanya berkaitan dengan kebutuhan akan kebutuhan pokok yaitu makan dan minum ( Dinar, 2018). Tetapi, konsumsi yang ada merupakan pemenuhan akan kebutuhan pokok 
(makan dan minum), serta untuk pemenuhan kebutuhan sandang dan papan. Hal ini harus dilaksanakan secara terencana sesuai dengan kebutuhan dan anggaran yang tersedia. Jangan sampai mencapai pada "besar pasak, daripada tiang" yaitu lebih besar pengeluaran daripada pendapatan. Sehingga, konsumen dituntut menjadi konsumen yang rasional dalam berkonsumsi, jangan sampai menjadi konsumen yang konsumtif.

\section{KAJIAN TEORI}

Konsumsi adalah suatu tindakan manusia dalam mengurangi atau menghabiskan kegunaan suatu barang/ jasa untuk memenuhi kebutuhan. Soeharno (2006: 6) menjelaskan bahwa konsumsi adalah kegiatan memanfaatkan barang atau jasa dalam memenuhi kebutuhan hidup. Sedangkan, menurut Miller (2010: 25) "konsumen merupakan setiap orang yang membeli atau menggunakan suatu produk". Perilaku konsumsi masing-masing orang berkaitan dari sikap lingkungan hidup dan cara hidupnya serta pendapatan. Tujuan seseorang melakukan konsumsi adalah untuk memenuhi kebutuhan hidup, mengurangi nilai guna barang/ jasa, dan memperoleh kepuasan. Orang yang rasional dalam berkonsumsi akan menghemat sebagian uang yang dimilikinya untuk konsumsi dan menggunakan sisa uang untuk menabung. Seseorang dianggap bertindak rasional apabila mereka mempertimbangkan semua aspek dan alternatif yang memberinya utilitas paling tinggi (Suprapti, 2010). Hal ini harus tetap mempertimbangkan lingkungan ekonomi yang meliputi pendapatan, harga, tabungan, kredit, serta kondisi ekonomi secara umum (Malhotra, 2007: 78).

Namun, beberapa fenomena yang turut menjadi latar belakang dalam penelitian ini adalah sektor perekonomian yaitu sektor usaha dagang sangat berpengaruh penting dalam perilaku konsumsi. Bayangkan saja jika kita pernah melintasi sepanjang jalan Desa Bandaran, Kecamatan Tlanakan, Kabupaten Pamekasan, banyak sekali ditemui pedagang mulai dari pedagang yang berjualan aneka makanan, kebutuhan pokok, kebutuhan sandang, dsb yang berjejer di sepanjang jalan. Merunut hal tersebut ini dapat menjelaskan bahwa pola konsumsi yang dapat terlihat dalam masyarakat pesisir Desa Bandaran, Kecamatan Tlanakan, Kabupaten Pamekasan dapat tergolong sangat konsumtif. Kesimpulan awal yang dapat dijadikan asumsi dalam penelitian ini yaitu, dengan perbandingan jika perilaku konsumsi semakin tinggi (intensitas pembelian semakin sering), maka jumlah pedagang yang berjualan akan semakin banyak.

Sedangkan, dalam ekonomi Islam, tujuan konsumsi adalah memaksimalkan maslahah. Menurut Imam Shatibi, istilah maslahah maknanya lebih luas dari sekedar utility atau kepuasan dalam terminologi ekonomi konvensional. Maslahah merupakan tujuan hukum syara' yang paling utama. Maslahah adalah sifat atau kemampuan barang dan jasa yang mendukung elemen-elemen dan tujuan dasar dari kehidupan manusia di muka bumi ini (Machasin, 2003). Ada lima elemen dasar, yakni: agama, kehidupan atau jiwa (al-nafs), properti atau harta benda (al-mal), keyakinan (al-din), intelektual (al-aqD), dan keluarga atau keturunan (al-nas). Dengan kata lain, maslahah meliputi integrasi manfaat fisik dan unsurunsur keberkahan. 
Mencukupi kebutuhan dan bukan memenuhi kepuasan/ keinginan adalah tujuan dari aktivitas ekonomi Islam, dan usaha pencapaian tujuan itu adalah salah satu kewajiban dalam beragama. Menurut (Qardhawi: 2001) menjelaskan bahwa adapun sifat-sifat maslahah sebagai berikut: maslahah bersifat subyektif dalam arti bahwa setiap individu menjadi hakim bagi masing-masing dalam menentukan apakah suatu maslahah atau bukan bagi dirinya. Namun, berbeda dengan konsep utility, kriteria maslahah telah ditetapkan oleh syariah dan sifatnya mengikat bagi semua individu (Basyir, 1985). Maslahah orang per orang akan konsisten dengan maslahah orang banyak. Konsep ini sangat berbeda dengan konsep pareto optimum (Karim, 2000), yaitu keadaan optimal dimana seseorang tidak dapat meningkatkan tingkat kepuasan atau kesejahteraannya tanpa menyebabkan penurunan kepuasan atau kesejahteraan orang lain. Konsep maslahah mendasari semua aktivitas ekonomi dalam masyarakat, baik itu produksi, konsumsi, maupun dalam pertukaran dan distribusi (Rahman, 1975).

Dalam Islam, konsumsi tidak dapat dipisahkan dari peranan keimanan. Peranan keimanan menjadi tolak ukur penting karena keimanan memberikan cara pandang yang cenderung mempengaruhi perilaku dan kepribadian manusia. Menurut Askari dkk (2014) menyatakan bahwa keimanan sangat mempengaruhi kuantitas dan kualitas konsumsi baik dalam bentuk kepuasan material maupun spiritual, yang kemudian membentuk kecenderungan perilaku konsumsi di pasar. Tiga karakteristik perilaku ekonomi dengan menggunakan tingkat keimanan sebagai asumsi, (Kahf, 1999) yaitu:

a) Ketika keimanan ada pada tingkat yang cukup baik, maka motif berkonsumsi atau berproduksi akan didominasi 3 motif utama; maslahah, kebutuhan, dan kewajiban.

b) Ketika keimanan ada pada tingkat yang kurang baik, maka motifnya tidak didominasi hanya 3 hal tadi tapi juga kemudian akan dipengaruhi secara signifikan oleh ego, rasionalisme (materialisme), dan keinganan yang bersifat individualistis.

c) Ketika keimanan ada pada tingkat yang buruk, maka motif berekonomi tentu saja akan didominasi oleh nilai-nilai individualistis (selfishness), ego, keinginan, dan rasionalisme.

Berkenaan dengan perilaku konsumtif perlu dianalisis melalui pemahaman mengenai perilaku konsumen. Pada dasarnya perilaku konsumen dalam membeli dipengaruhi oleh tiga faktor yaitu: 1) pengaruh lingkungan, 2) perbedaan dan pengaruh individual, dan 3) proses psikologis. Dalam pengambilan keputusan, konsumen juga dipengaruhi oleh: 1) budaya, 2) kelas sosial, 3) pengaruh pribadi, 4) keluarga, dan 5) situasi; keadaan yang mampu merubah tingkah laku seorang konsumen (Engel, 1994).

Perilaku konsumsi diartikan sebagai suatu tindakan guna mengurangi atau menghabiskan nilai guna suatu barang. Menurut Engel (1994: 3) perilaku konsumen adalah tindakan yang langsung terlibat untuk mendapatkan, mengkonsumsi dan menghabiskan barang/ jasa proses keputusan yang mendahului dan mengikuti tindakan. Sedangkan Kotler (2008: 183) mengemukakan bahwa perilaku konsumen dipengaruhi oleh faktor budaya, sosial, pribadi, dan psikologis. 
Berdasarkan pada uraian yang telah dipaparkan di atas, maka dalam penelitian ini ingin diteliti tentang bagaimana tinjauan perilaku konsumtif masyarakat pesisir dalam Islam (studi kasus pada masyarakat pesisir Desa Bandaran, Kecamatan Tlanakan, Kabupaten Pamekasan).

\section{Hasil dan Pembahasan}

\section{Perilaku Konsumsi Masyarakat Pesisir Di Desa Bandaran, Kecamatan Tlanakan, Kabupaten Pamekasan}

Kegiatan konsumsi merupakan salah satu kegiatan yang pokok dalam sendi kehidupan makhluk hidup. Dalam hal ini, terkadang konsumsi yang dimaksud adalah tidak hanya berkaitan dengan kebutuhan akan kebutuhan pokok yaitu makan dan minum (Septiana, 2015). Tetapi, konsumsi yang ada merupakan pemenuhan akan kebutuhan pokok (makan dan minum), serta untuk pemenuhan kebutuhan sandang dan papan. Hal ini harus dilaksanakan secara terencana sesuai dengan kebutuhan dan anggaran yang tersedia. Jangan sampai mencapai pada "besar pasak, daripada tiang" yaitu lebih besar pengeluaran daripada pendapatan. Sehingga, konsumen dituntut menjadi konsumen yang rasional dalam berkonsumsi, jangan sampai menjadi konsumen yang konsumtif.

Masyarakat di Desa Bandaran, Kecamatan Tlanakan, Kabupaten Pamekasan mereka merupakan masyarakat yang tergolong memiliki kemauan yang cukup besar dalam bidang ekonomi. Dengan mayoritas bekerja sebagai nelayan, meraka mencari nafkah pagi, siang, sore dan bahkan malam. Sekalipun mereka memiliki semangat dalam urusan ekonomi dan konsumsinya, namun masyarakat di Desa Bandaran, Kecamatan Tlanakan, Kabupaten Pamekasan juga termasuk masyarakat yang tidak lupa akan hal agama dan pendidikannya.

Hal terbukti dengan hasil observasi dalam pengambilan data penelitian bahwa diadakan pengajian dan sholat berjamaah di setiap malam Jum'at secara menyuluruh. Selain itu, yang perlu ditekankan dalam penemuan data di lapangan bahwa masyarakat di Desa Bandaran, Kecamatan Tlanakan, Kabupaten Pamekasan menjadikan malam jumat dan hari jumat sebagai hari libur kerja bagi masyarakatnya. Sedangkan dalam bidang pendidikan, para remajanya masih mementingkan ilmu pengetahuan yang mampu diperoleh dari bidang pendidikan. Temuan di lapangan menyatakan bahwa rata-rata remaja di desa ini memilih melanjutkan ke jenjang yang lebih tinggi, seperti jenjang S1 bahkan S2.

Masyarakat masyarakat di Desa Bandaran, Kecamatan Tlanakan, Kabupaten Pamekasan merupakan sosok pekerja yang semangat, tekun, dan ulet dalam mencari nafkah untuk memenuhi kebutuhan keluarga. Dengan karakteristik masyarakat yang seperti ini menjadikan masyarakat mampu dengan mudah dalam pemenuhan kebutuhan pokok, sampai pada kebutuhan sandang dan papan. Terbukti dengan intensitas konsumsi yang sangat tinggi, sedangkan jika dalam hal kebutuhan sandang dan papan terlihat pada banyaknya bangunan yang digunakan sebagai tempat tinggal dengan kategori mewah di sepanjang jalan di Desa Bandaran, Kecamatan Tlanakan, Kabupaten Pamekasan. 
Masyarakat Desa Bandaran, Kecamatan Tlanakan, Kabupaten Pamekasan tergolong sbagai masyarakat yang kompak, peduli antar sesama, agamis, dan pekerja keras. Hal ini didukung dengan temuan di lapangan, pada malam Jum'at dan hari Jum'at shaf pada jamaah sampai penuh, berbeda dengan hari-hari biasanya yaitu hanya mencapai $2 \mathrm{~s} / \mathrm{d} 4$ shaf. Pandangan yang berkembang dan merupakan sebuah keyakinan akan adanya pertolongan Allah SWT, sehingga mereka yakin jika ada usaha pasti ada jalan. Mereka meliburkan pekerjaannya pada malam Jum'at dan hari Jum'at untuk beribadah kepada Allah SWT di masjid-masjid desa.

Selain itu, masyarakat di sana adalah masyarakat yang peduli antar sesama. Hal ini terbukti dengan ketika ada kifayah di desa itu sejauh apapun tempatnya, asalkan masih satu desa mereka pasti akan hadir ke tempat tersebut untuk takziyah atau sekedar membantu keluarga yang dikenai kifayah itu lalu mereka mendoakan dan ikut serta dalam tahlilan bersama.

Masyarakat Desa Bandaran, Kecamatan Tlanakan, Kabupaten Pamekasan dalam hal perilaku konsumsinya bisa dikatakan boros. Berdasarkan temuan di lapangan, peneliti dapat menyimpulkan bahwa pada umumnya tipikal masyarakat yang membelanjakan semua pendapatan yang diperoleh untuk memenuhi kebutuhan dan keinginannya. Kecenderungan yang terjadi yaitu ketika mereka memperoleh pendapatan, mereka langsung membelanjakannya dengan boros. Hal yang paling mengejutkan dari beberapa responden yang menjadi obyek penelitian yaitu bahkan mereka menghabiskan pendapatan yang diperoleh pada hari itu juga untuk memenuhi kebutuhan dan keinginannya.

Sebagai contoh dari hasil wawancara yang dilakukan kepada para responden bahwa mereka menghabiskan pendapatan yang diperoleh pada hari itu juga untuk memenuhi kebutuhan dan keinginannya, seperti membeli bahan bangunan untuk memperindah atau merenovasi rumah sebagai tempat tinggal, membeli perhiasan, dan beras sebagai pemenuhan kebutuhan pokok yang utama. Berkembang pula jika pendapatan yang diperoleh dari tangkapan hasil laut mujur dalam masyarakat Desa Bandaran, Kecamatan Tlanakan, Kabupaten Pamekasan terdapat sebagian keluarga yang tidak memasak di rumah, tetapi membeli di luar. Hal ini justru akan bertolak belakang, jika pendapatan yang diperoleh dari tangkapan hasil laut tidak mujur, mereka akan mulai berhemat. Di desa ini juga masih memberlakukan barter seperti menukar ikan dengan beras ikan dengan minyak dan yang lainnya untuk memenuhi kebutuhan konsumsi mereka.

\section{Perilaku Konsumtif Masyarakat Pesisir dalam Tinjauan Islam Di Desa Bandaran, Kecamatan Tlanakan, Kabupaten Pamekasan}

Masyarakat Desa Bandaran, Kecamatan Tlanakan, Kabupaten Pamekasan dalam hal konsumsi dapat dikatakan tergolong boros atau sangat konsumtif. Hal ini diperoleh dari 12 orang sebagai responden yang diambil secara acak dengan latar belakang umur, pendidikan, serta pekerjaan yang berbeda. Berdasarkan responden tersebut, hanya 2 orang responden yang mengatakan bahwa perilaku konsumsi itu tergantung pada masing-masing individu. Sedangkan, 10 orang responden di Desa Bandaran, Kecamatan Tlanakan, 
Kabupaten Pamekasan menjelaskan bahwasanya perilaku konsumsi warga masyarakat tergolong boros. Hal ini dapat dibuktikan dengan beberapa potongan wawacara dari temuan di lapangan yang menyatakan bahwa:

"Mereka adalah tipikal masyarakat yang menghabiskan semua pendapatannya terhadap kemauan mereka. Ketika mereka mempunyai pendapatan, mereka langsung membelanjakannya dengan boros. Mereka biasanya menghabiskan pendapatan mereka pada hari itu juga untuk memenubi keinginan mereka, uang yang mereka dapat dibelanjakannya terbadap kebutuban dan keinginan mereka".

Banyak faktor yang memengaruhi seseorang melakukan pembelian terhadap suatu produk. Produsen perlu mempelajari faktor-faktor tersebut agar program pemasarannya dapat lebih berhasil. Faktor-faktor tersebut diantaranya adalah faktor ekonomi, psikologis, sosiologis, dan antropologis. Teori perilaku konsumen (consumer behavior) mempelajari bagaimana manusia memilih diantara berbagai pilihan yang dihadapinya dengan memanfaatkan sumberdaya (resources) yang dimilikinya. Sedangkan Kotler (2008: 183) mengemukakan bahwa perilaku konsumen dipengaruhi oleh faktor budaya, sosial, pribadi, dan psikologis.

\section{1) Faktor Budaya}

Kebudayaan merupakan faktor penentu yang pokok dari keinginan dan perilaku seseorang. Bila makhluk lainnya bertindak berdasarkan naluri, maka perilaku manusia pada umumnya dipelajari. Seorang anak yang sedang tumbuh mendapatkan seperangkat nilai, persepsi, preferensi, dan perilaku melalui proses sosialisasi yang melibatkan keluarga dan lembaga sosial lainnya. Faktor budaya mencakup; sub budaya dan kelas sosial yang ada di lingkungan masyarakat.

Jika dilihat saat ini sudah sangat sulit mampu melestarikan budaya, agar tetap terjaga dan merupakan warisan untuk anak dan cucu kita. Budaya perlu dijaga sebagai salah satu bukti kecintaan kita pada sebuah daerah. Temuan di lapangan bahwa faktor kebuadayaan sangat mempengaruhi perilaku konsumsi, bahkan kecintaan akan sebuah kebudayaan dapat menimbulkan perilaku konsumtif masyarakat. Dapat dicontohkan dari hasil wawancara dengan Bapak Ridwan yang menyatakan bahwa:

"Masyarakat Desa Bandaran, Kecamatan Tlanakan, Kabupaten Pamekasan adalah masyarakat yang peduli antar sesama dan terus memelihara ajaran Islam yang sangat kuat. Misalnya dengan ketika ada kifayah di desa itu sejauh apapun tempatnya, asalkan masih satu desa mereka pasti akan hadir ke tempat tersebut untuk takziyah atau sekedar membantu keluarga yang dikenai kifayah itu lalu mereka mendoakan dan ikut serta dalam tablilan bersama".

Berdasarkan hal tersebut dapat disimpulkan bahwa kepedulian antar sesama turut mendorong pelestarian sebuah kebudayaan. Tahlilan merupakan salah satu bentuk budaya dalam Islam dengan tujuan mendo'akan bagi yang meninggal dunia. Pada umumnya budaya tahlilan ini memiliki makna yang sangat dipegang teguh oleh umat muslim. Selain itu, berkenaan dengan acara tahlilan biasanya menghidangkan aneka kue yang memiliki 
makna tertentu. Misalnya, jika pada tahlilamn malam ke-3 wajib menyajikan kue apem dan nagasari. Sehingga, akan mendorong pembelian bahan-bahan tertentu dalam penyajian aneka kue pada malam ke-3 semakin besar. Hal ini mungkin sebagian kecil yang dicontohkan, namun pada dasarnya sangat banyak budaya khususnya untuk umat muslim dalam acara tahlilan.

Dalam satu sisi, pelestarian seperti ini sangat perlu dilestarikan karena ikut menyumbangkan warisan budaya tetap terjaga. Selain itu, acara tahlilan dihadiri oleh para tetangga, kerabat dari keluarga yang ditinggalkan. Dalam Islam, hal ini turut menjaga ukhuwah islamiah karena mampu menghadirkan banyak orang dalam tahlilan ini. Terdapat sebuah kepercayaan bahwa semakin banyak yang datang dalam acara tahlilan, menandakan bahwa yang meninggal dunia termasuk orang baik, banyak orang yang ingin turut mendo'akannya. Di sisi lain, acara tahlilan mendorong pembelian yang semakin tinggi (terutama kebutuhan akan konsumsi), sehingga menimbulkan perilaku konsumtif. Namun, konsumtif ini dilihat dalam ajaran Islam termasuk diperbolehkan asalkan tidak bermewah-mewahan dan memaksakan. Tetap pada ukuran yang tergolong sesuai dengan kemampuan keluarga yang ditinggalkan.

\section{2) Faktor Sosial}

Faktor ini terdiri dari kelompok referensi seseorang terdiri dari seluruh kelompok yang mempunyai pengaruh langsung maupun tidak langsung terhadap sikap atau perilaku seseorang, serta keluarga yang dapat memberikan pengaruh yang kuat terhadap perilaku pembeli. Keluarga merupakan organisasi penting dalam masyarakat dan menjadi kelompok acuan primer yang paling berpengaruh.

Untuk melihat faktor ini terlihat dari beberapa responden menjelaskan bahwa ikatan kekeluargaan di Desa Bandaran, Kecamatan Tlanakan, Kabupaten Pamekasan. Dapat dicontohkan dari hasil wawancara dengan Bapak Anton yang menyatakan bahwa:

"Masyarakat Desa Bandaran, Kecamatan Tlanakan, Kabupaten Pamekasan dalam salah satu perayaan acara pernikahan yang diadakan masyarakat di desa ini akan menyugubkan kemeriahan. Semua warga desa saling membantu demi terselenggaranya acara tersebut. Misalnya, bantuan yang diberikan berupa materïl yaitu sumbangan dalam bentuk uang dan segala kebutuban yang diperlukan dalam acara tersebut".

Hal yang seperti ini akan mendorong tingkat pembelian yang semakin tinggi, sehingga arus perputaran uang akan semakin cepat. Dapat disimpulkan perilaku konsumtif masyarakat pesisir di Desa Bandaran, Kecamatan Tlanakan, Kabupaten Pamekasan, pada satu sisi tergolong perilaku konsumtif yang kecenderungan tinggi. Tetapi, dalam hal fakor sosial yang mempengaruhi perilaku konsumsi dapat menumbuhkan pendidikan karakter diantara masyarakat setempat. Pendidikan tidak hanya diperoleh dari bangku sekolah. Terbukti tradisi keluarga yang mempengaruhi perilaku konsumsi dengan saling membantu ini tetap bertahan di tengah zaman yang semakin modern ini. Jika dilihat kepedulian seperti ini akan tetap menjalin tali persaudaraan dengan jalan silaturahmi. Islam 
menjelaskan bahwa dengan terus menyambung tali silaturahmi, akan memperpanjang usia dan memperbanyak rezeki.

\section{3) Faktor Pribadi}

Faktor ini lebih melihat secara personal seorang individu meliputi: 1) Umur dan tahapan dalam siklus hidup; seseorang akan mengubah barang dan jasa yang mereka beli selama hidupnya, 2) Jenis pekerjaan; pekerjaan seseorang juga memengaruhi barang/ jasa yang dibelinya, 3) Keadaan ekonomi; terdiri dari pendapatan yang dapat dibelanjakan, tabungan, dan hartanya, 4) Gaya hidup; pola seseorang dalam menjalani hidupnya (aktivitas, minat, kesukaan, sikap, konsumsi, dan harapan), serta 5) Kepribadian dan konsep diri; karakteristik psikologis yang berbeda dari setiap orang yang memandang responnya terhadap lingkungannya.

Faktor pribadi ini cukup kompleks dalam mempengaruhi perilaku konsumsi seorang individu maupun keluarga. Terlihat bahwa antara umur \& tahapan dalam siklus hidup, jenis pekerjaan, keadaan ekonomi, gaya hidup, serta kepribadian \& konsep diri saling mempengaruhi. Di sini akan disajikan beberapa hasil wawancara dari beberapa responden untuk mendukung temuan penelitian, antara lain:

"Mayoritas nelayan sebagai pekerjaan masyarakat di Desa Bandaran, Kecamatan Tlanakan, Kabupaten Pamekasan, yang mana hal ini, ada dua kategori jenis nelayan. Pertama, disebut dengan mancing yaitu berangkat pagi hari dan pulang sore hari. Kedua, Nelayan yaitu berangkat malam pulang malam, terkadang berangkat pagi hari dan pulang malam hari. Apabila dipersentasikean PNS (15\%), Wiraswasta (35\%), dan Nelayan (50\%)".

Berdasarkan beberapa wawancara di atas, dapat disimpulkan bahwa mayoritas jenis pekerjaan di Desa Bandaran, Kecamatan Tlanakan, Kabupaten Pamekasan adalah nelayan. Faktor pribadi ini cukup kompleks dalam mempengaruhi perilaku konsumsi seorang individu maupun keluarga. Terlihat bahwa antara umur \& tahapan dalam siklus hidup, jenis pekerjaan, keadaan ekonomi, gaya hidup, serta kepribadian \& konsep diri saling mempengaruhi. Secara berurutan, umur dan tahapan konsumsi seorang individu maupun keluarga, akan seiring meningkat jenis kebutuhannya dengan pertambahan umur dan jumlah anggota keluarga yang ada.

Turut juga dalam jenis pekerjaan akan mempengaruhi tingkat pendapatan yang kan menunjukkan bagaimana keadaan ekonomi sebuah keluarga. Jenis pekerjaan juga akan mempengaruhi gaya hidup baik individu maupun keluarga dalam berperilaku konsumsi, serta kepribadian. Misalnya, kepribadian dalam hal peduli antar sesama. Terlihat dari hasil di lapangan menunjukkan tingkat solidaritas masyarakat Desa Bandaran, Kecamatan Tlanakan, Kabupaten Pamekasan sangat baik dan kuat. Dalam ajaran Islam memperkuat tali persaudaraan juga sangat dianjurkan, saling membantu antar sesama dan ikut merasakan penderitaan antar sesama.

\section{4) Faktor Psikologis}

Faktor ini lebih melihat kondisi psikis yang dimiliki individu meliputi: 1) Motivasi adalah dorongan yang menggerakkan perilaku dan memberikan arah dan tujuan bagi 
perilaku seseorang, 2) Persepsi sebagai proses dimana seseorang memilih, mengorganisasikan, mengartikan masukan informasi untuk menciptakan suatu gambaran yang bermakna, 3) Proses belajar menjelaskan perubahan dalam perilaku seseorang yang timbul dari pengalaman, serta 4) Kepercayaan dan sikap suatu gagasan deskriptif yang dimiliki seseorang terhadap sesuatu.

Faktor ini merupakan faktor yang sangat melekat dari masing-masing individu karean sangat abstrak untuk dapat dilihat. Motivasi dapat terlihat pada dorongan masyarakat Desa Bandaran, Kecamatan Tlanakan, Kabupaten Pamekasan. Hal ini terlihat pada saat masyarakat memperoleh pendapatan yang besar, kecenderungan semakin konsumtif dalam berkonsumsi. Misalnya, membeli bahan bangunan, perhiasan, makan di luar dengan tidak memasak.

Untuk sub persepsi, terlihat bahwa ketika pendapatan yang diperoleh sangat besar tersirat bahwa uang tersebut harus dibelanjakan untuk pemenuhan kebutuhan keluarga. Mungkin jika dilihat dari segi proses belajar, pada umumnya memiliki tingkat pendidikan rendah. Tetapi, pendidikan tidak hanya dapat diperoleh dari bangku sekolah tetapi dapat diperoleh dari pengalaman dan sosialisasi yang terus dilakukan oleh masyarakat Desa Bandaran, Kecamatan Tlanakan, Kabupaten Pamekasan. Sedangkan, untuk sub kepercayaan dan sikap suatu gagasan deskriptif yang dimiliki seseorang terhadap sesuatu. Timbul karena merupakan hasil dari pengalaman yang terus dikembangkan oleh masyarakat demi terjalinnya ukhuwah islamiyah.

\section{Masyarakat Pesisir Di Desa Bandaran, Kecamatan Tlanakan, Kabupaten \\ Pamekasan Memaknai Kata "Maslahah" dalam Perilaku Konsumsinya}

Perilaku konsumsi Islam berdasarkan tuntunan Al-Qur'an dan Hadits perlu didasarkan atas rasionalitas yang disempurnakan yang mengintegrasikan keyakinan kepada kebenaran yang melampaui rasionalitas manusia yang sangat terbatas ini. Bekerjanya invisible hand yang didasari oleh asumsi rasionalitas yang bebas nilai tidak memadai untuk mencapai tujuan ekonomi Islam. Selain itu, yang menjadi titik tekan dalam konsumsi yaitu mengenal istilah "Maslahah" (Siddiqi, 1972) seperti yang ditunjukkan dalam formulasi di bawah ini:

$$
\mathrm{M}=\mathrm{F}(1+\beta \mathrm{ip}) \delta \gamma
$$

\section{Keterangan:}

$$
\begin{array}{ll}
\mathrm{M} & =\text { Maslahah } \\
\mathrm{F} & =\text { Manfaat fisik } \\
\mathrm{Bi} & =\text { Frekuensi kegiatan } \\
\mathrm{p} & =\text { Pahala per unit kegiatan }
\end{array}
$$

Berdasarkan dari hal yang telah dijabarkan di atas menunjukkan bahwa masyarakat Desa Bandaran, Kecamatan Tlanakan, Kabupaten Pamekasan sangat peduli antar sesama dan menjujung kemaslahatan dalam melakukan kegiatan konsumsinya. Temuan di lapangan juga menunjukkan bahwa terdapat kesimpulan tentang strategi masyarakat Desa 
Bandaran, Kecamatan Tlanakan, Kabupaten Pamekasan dalam membangun kemaslahatan khususnya dalam bidang ekonomi.

Hal ini selaras dengan tinjauan pustaka yang menjelaskan bahwa konsumen yang merasakan adanya maslahah dan menyukainya akan tetap rela melakukan suatu kegiatan meski manfaat fisik dari kegiatan tersebut bagi dirinya sudah tidak ada. Pada dasarnya, maslahah tidak dapat diterima secara langsung setelah kita membagi apa yang kita dapatkan (rejeki). Tetapi, rasa ini akan diperoleh setelah kita merasa ikhlas tanpa ingin memperoleh balasan tersebut. Jadi, berbagi yang terpenting adalah ikhlas karena Allah SWT, pasti akan memperoleh ganti dari lainnya. Tidak harus memperoleh ganti dari orang yang kita beri, tetapi pasti jika ikhlas ada ganti dari lainnya.

Masyarakat Desa Bandaran mempunyai beberapa hal penting yang menurut mereka bisa menunjang kegiatannya tersebut yaitu melalui investasi pendapatan yang didapatkan, antara lain berupa:

1) Pemenuhan kebutuhan hidup tiap-tiap individu

Untuk pemenuhan kebutuhan individu biasanya berpatokan dengan skala prioritas yang dibutuhkan terlebih dahulu. Kemudian, melihat pada tingkat pendapatan yang diperoleh, terutama yang bekerja sebagai nelayan.

2) Pemenuhan kebutuhan hidup keluarga (membeli kebutuhan hidup keluarga)

Untuk hal pemenuhan kebutuhan hidup keluarga ini, mereka tidak semena-mena menginvestasikannya hanya berupa barang-barang kebutuhan pokok sehari-hari. Melainkan sebagian kelebihan dari hasil pendapatannya tersebut disimpan pada kegiatan arisan yang ada di desa atau ditabung. Jadi, untuk selanjutnya hasil dari arisan yang diperoleh nanti akan diinvestasikan lagi berupa tanah, membuka usaha (kecil atau besar), dan membuat rumah. Perlu diketahui bahwa sifat arisan yang setiap hari penyetorannya membuat tabungan mereka besar, walaupun tiap harinya kecil yang disetorkan arisan ini ada yang dikocok tiap bulan ada yang tiga bulan sekali, rata-rata masyarakat disana bisa membuat rumah membeli tanah bahkan membuka usaha karena hasil dari arisan tersebut. Selain itu, masyarakat di Desa Bandaran lebih intens menggunakan media arisan sebagai sarana investasi, daripada menabung di bank sebagai unit lembaga keuangan.

3) Pemenuhan kebutuhan jangka panjang

Mengenai pemenuhan kebutuhan jangka panjang ini, mereka lebih memilih dengan cara investasi emas (perhiasan). Hal ini karena, bagi mereka emas bukan hanya difungsikan sebagai perhiasan saja, melainkan sebagai simpanan jangka panjang. Selain itu, emas dijadikan sebagai antisipasi apabila terjadi kemacetan atau penurunan pendapatan (pemasukan) pada para nelayan tersebut. Sehingga, mereka akan mengambil langkah untuk menjual emasnya kembali guna memenuhi kelangsungan kebutuhan hidup mereka. Selain itu, mereka juga menabungkannya lewat anakankanya melalui tabungan sekolah.

4) Kekompakan berekonomi 
Masyarakat di Desa Bandaran adalah masyarakat yang kompak dan giat dalam ekonomi, misalnya jika Bapak sebagai nelayan, maka sebagian Ibu di rumah membuka usaha kecil bahkan besar untuk membantu mengurangi atau menambah pendapatan keluarga. Bahkan anak muda di sana, kalau yang masih sekolah menggunakan waktu sepulang sekolah mereka untuk membantu mencari uang untuk keluarga. Jika anak lelaki, akan ikut membantu Bapak untuk nelayan dan jika anak yang perempuan membantu Ibu yang membuka usaha di rumah.

\section{KESIMPULAN}

Perilaku konsumsi masyarakat pesisir dengan mayoritas bekerja sebagai nelayan, mereka mencari nafkah pagi, siang, sore dan bahkan malam. Sekalipun mereka memiliki semangat dalam urusan ekonomi dan konsumsinya. Perilaku konsumtif masyarakat pesisir dalam tinjauan Islam, dalam satu sisi, pelestarian seperti ini sangat perlu dilestarikan karena ikut mennyumbangkan warisan budaya tetap terjaga, serta turut menjaga ukhuwah islamiah karena mampu menghadirkan banyak orang dalam tahlilan ini. Serta dalam memaknai kata "Maslahah" pada perilaku konsumsinya sangat peduli antar sesama dan menjunjung kemaslahatan dalam melakukan kegiatan konsumsinya.

\section{DAFTAR PUSTAKA}

Askari, H., Iqbal, Z., \& Mirakhor, A. (2014). Understanding Development in an Islamic Framework. Islamic Economic Studies. https://doi.org/10.12816/0004129

Basyir, A. A. (1985). Garis-garis Besar Ekonomi Islam. Yogyakarta: BPFE.

Case, K. E. \& R. C. F. (2007). Prinsip-prinsip Ekonomi (8th ed.; 1, ed.). Jakarta: Erlangga.

Dinar \& Hasan. (2018). Pengantar Ekonomi: Teori Dan Aplikasi. In New York.

Engel, J. F. (1994). Perilaku konsumen jilid 1 / James F. Engel, Roger D. Blackwell, Paul W. Miniard; alih bahasa F.X. Budiyanto (Ed. 6). Jakarta: Binarupa Aksara.

Karim, A. A. (2000). Ekonomi Mikro Islami. In Rajawali Pers. https://doi.org/http://dx.doi.org/10.1016/j.mineng.2016.01.006

Kotler, P. \& Armstrong, G. (2008). Prinsip-Prinsip Pemasaran. Edisi 12. Jilid 1. In Manajemen Pemasaran. Jakarta: Erlangga.

Machasin. (2003). Islam Teologi Aplikatif. Yogyakarta: Pustaka Alief.

Malhotra, N. K. (2007). Marketing Research: An Applied Orientation, 5th Edition. Prentice-Hall, Inc, New Jersey, USA.

Miller, R. L. \& A. D. S. (2010). Economic Education for Consumers (4th ed.). USA: SouthWestern Cengage Learning.

Muhammad Dinar, M. H. (2018). Pengantar Ekonomi: Teori Dan Aplikasi. In New York. Qardhawi, Y. (2001). Dawr al-Qiyam wa al-Akhlaq fi al-Iqtisad al-Islami, diterjemabkean oleh 
Zainal Arifin dan dablia Husim, Norma dan Etika Ekonomi Islam. J: Gema Insani Press.

Rahman, A. (1975). Economic Doctrines of Islam. Lahore: Islamic Publications.

Septiana, Aldila, Pengaruh Economics Literacy terhadap Perilaku Konsumsi yang Dimediasi oleh Nilai-Nilai Budaya Lokal dan Promosi pada Siswa SMA Negeri Se Kota Pamekasan. Tesis tidak diterbitkan. Malang: PPs-UM, 2013.

Septiana, Aldila, Modul Pengantar Ilmu Ekonomi. Bangkalan: UTM Press, 2015.

Septiana, A. (2015). Analisis Perilaku Konsumen: Teori \& Praktik dalam Bidang Pemasaran. Bangkalan: UTM Press.

Siddiqi, M. N. (1972). Some Aspects of the Islamic Economy. Delhi: Markazi Maktaba Islami.

Soeharno. (2006). Teori Ekonomi Mikro. https://doi.org/10.1109/CVPR.2015.7298631

Suprapti, N. W. S. (2010). Perilaku konsumen: Pemahaman dasar dan aplikasinya dalam strategi pemasaran. In Bali: Universitas Udayana Bali. Bali: Udayana University Press. 